\title{
Screening of crude extracts of six medicinal plants used in South-West Nigerian unorthodox medicine for anti-methicillin resistant Staphylococcus aureus activity
}

\author{
Kabir O Akinyemi*, Olukayode Oladapo, Chidi E Okwara, Christopher C Ibe \\ and Kehinde A Fasure
}

Address: Department of Microbiology, Lagos State University, (LASU) Ojo. P.M.B 1087, Apapa, Lagos, Nigeria

Email: Kabir O Akinyemi* - akinyemiko@yahoo.com; Olukayode Oladapo - oladapokayode2005@yahoo.com;

Chidi E Okwara - okwaraclement@yahoo.com; Christopher C Ibe - ibechris2002ng@yahoo.com; Kehinde A Fasure -fasureak@yahoo.com

* Corresponding author

Published: II March 2005

BMC Complementary and Alternative Medicine 2005, 5:6 doi:10.1 I86/1472-6882-5-6

This article is available from: http://www.biomedcentral.com/1472-6882/5/6

(C) 2005 Akinyemi et al; licensee BioMed Central Ltd.

This is an Open Access article distributed under the terms of the Creative Commons Attribution License (http://creativecommons.org/licenses/by/2.0), which permits unrestricted use, distribution, and reproduction in any medium, provided the original work is properly cited.
Received: 10 October 2004

Accepted: II March 2005

\begin{abstract}
Background: Six Nigerian medicinal plants Terminalia avicennioides, Phylantus discoideus, Bridella ferruginea, Ageratum conyzoides, Ocimum gratissimum and Acalypha wilkesiana used by traditional medical practitioners for the treatment of several ailments of microbial and non-microbial origins were investigated for in vitro anti-methicillin Resistant Staphylococcus aureus (MRSA) activity.

Methods: Fresh plant materials were collected from the users. Water and ethanol extracts of the shredded plants were obtained by standard methods. The Bacterial cultures used were strains of MRSA isolated from patients. MRSA was determined by the reference broth microdilution methods using the established National Committee for Clinical Laboratory Standards break points. Staphylococcus aureus NCIB 8588 was used as a standard strain. Susceptibility testing and phytochemical screening of the plant extracts were performed by standard procedures. Controls were maintained for each test batch.
\end{abstract}

Results: Both water and ethanol extracts of $T$. avicennioides, P. discoideus, O. gratissimum, and A. wilkesiana were effective on MRSA. The Minimum Inhibition Concentration (MIC) and Minimum Bactericidal Concentration (MBC) of the ethanol extracts of these plants range from 18.2 to 24.0 $\mathrm{mcg} / \mathrm{ml}$ and 30.4 to $37.0 \mathrm{mcg} / \mathrm{ml}$ respectively. In contrast, MIC range of 30.6 to $43.0 \mathrm{mcg} / \mathrm{ml}$ and 55.4 to $71.0 \mathrm{mcg} / \mathrm{ml}$ were recorded for ethanol and water extracts of $B$. ferruginea, and $A$. conyzoides respectively. Higher MBC values were obtained for the two plants. These concentrations were too high to be considered active in this study. All the four active plants contained at least trace amount of anthraquinones.

Conclusion: Our results offer a scientific basis for the traditional use of water and ethanol extracts of A. wilkesiana, $O$. gratissimum, $T$. avicennioides and $P$. discoideus against MRSA-associated diseases. However, B. ferruginea and $A$. conyzoides were ineffective in vitro in this study; we therefore suggest the immediate stoppage of their traditional use against MRSA-associated diseases in Lagos, Nigeria. 


\section{Background}

Over the last three decades, methicillin resistant Staphylococcus aureus (MRSA) had caused major problems in hospitals throughout the world[1]. The first outbreak caused by MRSA occurred in European hospitals in the early 1960 's[2]. During the late 1970's, strains of S. aureus resistant to multiple antibiotics including methicillin and gentamycin were increasingly responsible for many outbreaks in the U.S.A and Great Britain[3], and by 1980's MRSA was considered a major clinical and epidemiological pathogen in human hospitals[4]. Since then strains of MRSA and coagulase-negative Staphylococci had spread worldwide. Recent reports indicated that MRSA strains account for 10 to $40 \%$ of $S$. aureus isolated from some European hospitals[5-7]

In many parts of the globe, particularly the developed countries, fluoroquinolones (pefloxacin, ciprofloxacin and ofloxacin) are recommended for serious infections associated with Staphylococci, although, occasional resistance among MRSA has been documented[2], Furthermore, in spite of recent reports of vancomycin resistant strains MRSA in some parts of the globe, vancomycin still remain the drug of choice for most MRSA-associated diseases[9].

The use of medicinal plants all over the world predates the introduction of antibiotics and other modern drugs into Africa continent. Herbal medicine has been widely used and formed an integral part of primary health care in China[10], Ethiopia[11], Argentina[12] and Papau New Guinea[13]. Traditional medical practitioners in Southwest, Nigeria, use a variety of herbal preparations to treat different kinds of microbial diseases including MRSAassociated diseases.

In recent times, the number of traditional healers claiming the efficacies of six medicinal plants viz: Terminalia avicennioides, Bridella ferruginea, Ageratum conyzoides Ocimum gratissimum, Acalypha wilkesiana and Phylantus discoideus for the cure of patients with $S$. aureus-associated diseases such as, eczema, carbuncles and osteomyelitis is on the increase.

Terminalia. avicennioides (Combretaceae) is a yellowish brown, hard and durable wood. The roots which are used as chewing sticks have been claimed to cure dental caries and skin infections[14]. Previous studies, showed that the bark extract of $T$. avicennioides exhibited both vibrocidal and typhoidal activities[15,16]. A. conyzoides (Compositae) is an annual herb abundant in preclusive forests and farmland in southern part of Nigeria. Previous study showed that methanolic leaf extracts corrected fibrinogaemia in poultry chicks. Also both methanol and water extracts of the leaves exhibited anti-bacterial effect[17]. B. ferruginea
(Euphorbiaceae) is used for treatment of insomnia. The bark in combination with other herbs is used to cure pile in western part of Nigeria[18].

Like other Ocimum spp, Ocimum gratissimum (Lamiaceae) traditionally called "Efirin-Aja" has been reported to have medicinal properties. The leaf extracts are popularly used for the treatment of diarrhea while the cold leaf infusions are used for the relief of stomach upset and haemorrhoids. The thymol-riched leaf has been reported to have antimicrobial properties[19]. Acalypha wilkesiana (Euphorbiaceae) is popularly used for the treatment of malaria, dermatological and gastrointestinal disorders[20]. The bark extract of P. discoideus (Euphorbiaceae) is used locally to cure stomachache and lumbago.

The reputed efficacies of these plants have been experienced and passed on from one generation to the other. Apparently, lack of scientific proof of efficacies claimed by traditional medical practitioners in Nigeria called for this study. The present study investigates effects of these medicinal plants against Methicillin Resistant $S$. aureus.

\section{Methods}

Fresh plant materials were collected from users of these plants in Imota, Ikorodu, Ojo and Kosofe in Lagos State, Nigeria. Their botanical identities were determined and authenticated by Mr. O. K. Oluwa in Botany department, Lagos State University, Ojo, Lagos. Samples were deposited in the department herbarium.

\section{Extraction}

The extraction method used in this study was a modification of Akinside \& Olukoya,[15] and Akinyemi et al.[16]. In line with the traditional methods of preparation, shredded plant materials were put in sterile bottles containing either distilled water or $40 \%$ ethanol.

\section{Water extract}

Leaves of B. ferruginea (P) and A. conyzoides, (Q), and stem barks of T. avicennioides (R) P. discoideus (S) O. gratissimum (T) and A. wilkesiana (U) were oven-dried at temperature of $60^{\circ} \mathrm{C}$ for 6 days. They were subsequently grounded into fine powder in $25 \mathrm{ml}$ of sterile distilled water, maintained at $60^{\circ} \mathrm{C}$ for $3 \mathrm{hr}$. The resulting suspensions were filtered and evaporated to dryness at $60^{\circ} \mathrm{C}$ in vacuo to produce $0.031,0.041,0.038,0.042,0.044$ and $0.035 \mathrm{~g}$ of $\mathrm{P}, \mathrm{Q}, \mathrm{R}$, $\mathrm{S}, \mathrm{T}$, and $\mathrm{U}$ respectively. They were further labeled as aqueous extracts and designated as PW, QW, RW SW, TW, and UW respectively.

\section{Ethanol extract}

Six grams of each of the powdered plant materials were put in a soxhlet extractor containing $25 \mathrm{ml}$ of $40 \%$ ethanol. The resulting extracts were subsequently weighed to 
produce $0.032,0.036,0.038,0.040,0.030$ and $0.034 \mathrm{~g}$ of $\mathrm{P}, \mathrm{Q}, \mathrm{R}, \mathrm{S}, \mathrm{T}$, and $\mathrm{U}$ respectively. They were labeled as ethanol extracts and designed PE, QE, RE, SE, TW and UW respectively.

\section{Bacterial culture}

The MRSA strains used in this study were clinical isolates from urethral swab, seminal fluid, urine, high virginal swab, blood, skin swab and sputum of patients presenting with symptoms of $S$. aureus-associated diseases. The isolates were identified by standard method[21]. Methicillin resistant $S$. aureus was determined by the reference broth microdilution methods using the established NCCLS[22] break points. The standard strain used was $S$. aureus

NCIB 8588. The organisms were maintained on agar slope at $4{ }^{\circ} \mathrm{C}$ and sub-cultured for $24 \mathrm{hr}$ before use.

\section{Bacterial susceptibility testing}

A standardized inoculum $\left(1-2 \times 10^{7} \mathrm{cfu} / \mathrm{ml} 0.5 \mathrm{McFar}-\right.$ land standards) was introduced onto the surface of sterile agar plates, and a sterile glass spreader was used for even distribution of the inoculum. A sterile paper disc previously soaked in a known concentration of extract (20 $\mathrm{mcg} / \mathrm{ml}$ per disc) was carefully placed at the centre of the labeled seeded plate. The same procedure was used for all the MRSA strains used. The plates were incubated aerobically at $37^{\circ} \mathrm{C}$ and examined for zones of inhibition after $24 \mathrm{hr}$. The inhibition zones were measured with a ruler and compared with the control disc23 (disc containing only physiological saline).

\section{Determination of minimum inhibitory concentration (MIC) and minimum bactericidal concentration (MBC)} MIC of the extracts was determined by dilution of $P, Q, R$, $\mathrm{S}, \mathrm{T} \&$.U to various concentrations of $0.0-32,0.0-91,0.0-$ $38,0.0-42,0.0-44$ and $0.0-35 \mathrm{mcg} / \mathrm{ml}$ respectively. Equal volume of each extract and nutrient broth were mixed in a test tube. Specifically $0.1 \mathrm{ml}$ of standardized inoculum $\left(1-2 \times 10^{7} \mathrm{cfu} / \mathrm{ml}\right)$ was added to each tube. The tubes were incubated aerobically at $37^{\circ} \mathrm{C}$ for $18-24 \mathrm{hr}$. Two control tubes were maintained for each test batch. These included antibiotic control (tube containing extract and the growth medium without inoculum) and organism control (the tube containing the growth medium, physiological saline and the inoculum). The lowest concentration (highest dilution) of the extract that produced no visible bacterial growth (no turbidity) when compared with the control tubes was regarded as MIC. However, the $\mathrm{MBC}$ was determined by subculturing the test dilution on to a fresh drug-free solid medium and incubated further for 18-24 hr. The highest dilution that yielded no single bacterial colony on a solid medium was taken as MBC.

\section{Phytochemical screening methods}

All plant parts were extracted on the day of collection. The screening procedures were adapted from Wall et al.,[24] and Sofowora[25]. An extraction of each plant part was prepared by macerating a known weight of the fresh plant material in a blender with redistilled methylated spirit. Each extract was suction-filtered and the process repeated until all soluble compounds had been extracted, as judged by loss of colour of the filtrate. Extract from each plant part was evaporated to dryness in vacuo at about $45^{\circ} \mathrm{C}$ and further dried to a constant weight at the same temperature in a hot-air oven. A portion of the residue was used to test for plant constituents.

The test for tannins was carried out by subjecting $3 \mathrm{~g}$ of each plant extract in $6 \mathrm{ml}$ of distilled water, filtered and ferric chloride reagents added to the filtrate. For cardiac glycosides, legal test and the Killer-Kiliani test[26] were adopted $(0.5 \mathrm{~g}$ of extract was added to $2 \mathrm{ml}$ acetic anhydrate plus $\mathrm{H}_{2} \mathrm{SO}_{4}$ ). The test for alkaloids was carried out by subjecting $0.5 \mathrm{~g}$ aqueous extract in $5 \mathrm{ml} 1 \% \mathrm{HCl}$, boiled, filtered and Mayer's reagent added [26,27]. Cyanogenic glycosides were identified by subjecting $0.5 \mathrm{~g}$ extract in $10 \mathrm{ml}$ sterile water, and were filtered. Sodium picrate paper was added to the filtrate and heated to boil. The extract was also tested for carbohydrates using resorcinol solution[24]. The extract was subjected to frothing test for the identification of saponin. Haemolysis test was further performed on the froted extracts in water to remove false positive results[25]. Fehling's solution was added to the extract and heated to detect reducing sugar. The extract was also tested for free glycoside bound anthraquinones[24,25]. Five grams of extract was added to $10 \mathrm{ml}$ benzene, filtered and ammonia solution added. The presence of flavonoids was determined using $1 \%$ aluminum chloride solution in methanol concentrated $\mathrm{HCl}$, magnesium turnins, and potassium hydroxide solution[28].

\section{Results}

The profile of six medicinal plants used in this study is shown in Table 1. The results of antibacterial activity of the crude extracts of these plants revealed that only four of the six plants: T. avicennioides, $P$. discoideus, O. gratissimum and A. wilkesiana showed good antibacterial activity against MRSA used.

Both water and ethanol extracts of these plants were effective on MRSA strains. On the other hand, the crude extracts (water \& ethanol) of B. ferruginea and A. conyzoides were weakly effective against the cocci as judged by the zones of inhibition (Table 2). The MIC and MBC values obtained for the extracts against the MRSA varied from one plant extract to the other. For instance, the MIC values of 20.8 and $18.2 \mathrm{mcg} / \mathrm{ml}$ were obtained for water and 
Table I: Profile of the six medicinal plants used

\begin{tabular}{|c|c|c|c|c|}
\hline Botanical Name & Family & Local name & Plant part used & Voucher Number \\
\hline Bridella ferruginea Engl. & Euphorbiaceae & Ira Odun & Leaf & LSH \\
\hline Ageratum conyzoides Linn. & Compositae & Imi-Isu & Leaf & LSH \\
\hline Terminalia avicennioides Guill \& Perr. & Combretaceae & Idi & Bark & LSH \\
\hline Phylantus discoideus muel. Muel-Arg. & Euphorbiaceae & Asin & Bark & LSH \\
\hline Ocimum gratissimum Linn. & Lamiaceae & Efirin Aja & Leaf & LSH \\
\hline Acalypha wilkesiana Muell-Arg. & Euphorbiaceae & Eweeala & Leaf & LSH \\
\hline
\end{tabular}

Table 2: Antibacterial activity of the crude plant extracts on MRSA

\begin{tabular}{|c|c|c|c|c|}
\hline \multirow[t]{2}{*}{ Plants used } & \multicolumn{2}{|c|}{ MRSA $(n=23)$} & \multicolumn{2}{|c|}{ *S aureus } \\
\hline & Water extract & Ethanol extract & Water extract & Ethanol extract \\
\hline B. ferruginea & 2.6 & 4.7 & 2.4 & 4.6 \\
\hline A. conyzoides & 2.0 & 3.3 & 2.1 & 3.4 \\
\hline T. avicennioides & 12.2 & 17.6 & 12.0 & 18.0 \\
\hline P. discoideus & 11.5 & 16.0 & 11.2 & 16.1 \\
\hline O. gratissimum & 10.2 & 10.3 & 9.0 & 9.5 \\
\hline A. wilkesiana & 8.3 & 9.5 & 8.2 & 9.2 \\
\hline Methicillin & - & - & - & - \\
\hline Oxacillin & - & - & - & - \\
\hline
\end{tabular}

Activity key: Figures indicate average zone of inhibition (in $\mathrm{mm}),(-)=$ no inhibition, $* S$. aureus $(\mathrm{NCIB} 8588)=$ standard strain used. Methicillin \& Oxacillin $=($ commercial antibiotics $), \mathrm{n}=$ number of MRSA tested.

Table 3: Minimum inhibitory and bactericidal concentrations of plant extracts on MRSA.

\begin{tabular}{|c|c|c|c|c|}
\hline \multirow[t]{2}{*}{ Plant tested } & \multicolumn{2}{|c|}{ Water extract } & \multicolumn{2}{|c|}{ Ethanol extract } \\
\hline & MIC & MBC & MIC & MBC \\
\hline B. ferruginea & 55.4 & 63.6 & 30.6 & 55.0 \\
\hline A. conyzoides & 71.0 & 84.2 & 43.0 & 63.2 \\
\hline T. avicennioides & 20.8 & 33.0 & 18.2 & 30.4 \\
\hline P. discoideus & 23.0 & 34.2 & 20.5 & 33.0 \\
\hline O. gratissimum & 25.0 & 37.0 & 22.3 & 35.2 \\
\hline A. wilkesiana & 24.5 & 37.0 & 24. & 37.0 \\
\hline
\end{tabular}

Key: $\mathrm{mcg}=$ microgram

ethanol extracts of T. avicennioides respectively, while the corresponding $\mathrm{MBC}$ values are 33.0 and $30.4 \mathrm{mcg} / \mathrm{ml}$. The MIC and MBC values of 43.0 and $63.2 \mathrm{mcg} / \mathrm{ml}$ were recorded for ethanol extract and 71.0 and $84.2 \mathrm{mcg} / \mathrm{ml}$ for water extract of A. conyzoides respectively. Also, MIC \& $\mathrm{MBC}$ values of $55.4 \& 63.6 \mathrm{mcg} / \mathrm{ml}$ and $30.6 \& 55.0 \mathrm{mcg} /$ $\mathrm{ml}$ were obtained for water and ethanol extracts of $B$. ferruginea respectively. These plant extracts were bacterio- static at lower concentrations and bactericidal at higher concentrations as revealed by MIC and MBC values (Table $3)$.

The result of photochemical screening showed that all the six tested plants exhibited positive reactions to alkaloids, tannins and saponins. However, anthraquinone was only found in the four active plants in this study. None con- 
Table 4: Phytochemical analysis of six crude plant extracts

\begin{tabular}{|c|c|c|c|c|c|c|}
\hline \multirow[b]{2}{*}{ Components } & \multicolumn{6}{|c|}{ Screened plants. } \\
\hline & $\begin{array}{l}\text { B. ferruginea } \\
\text { (leaf) }\end{array}$ & $\begin{array}{l}\text { A. conyzoides } \\
\text { (leaf) }\end{array}$ & $\begin{array}{l}\text { T. avicenioides } \\
\text { bark) }\end{array}$ & $\begin{array}{l}\text { P. discoideus } \\
\text { (bark) }\end{array}$ & $\begin{array}{l}\text { O. gratissimum } \\
\text { (leaf) }\end{array}$ & $\begin{array}{l}\text { A. wilkesiana } \\
\text { (leaf) }\end{array}$ \\
\hline Alkaloids & ++ & ++ & ++ & +++ & ++ & ++ \\
\hline Tannins & ++ & ++ & +++ & +++ & +++ & ++ \\
\hline Saponins & ++ & ++ & +++ & +++ & ++ & ++ \\
\hline Anthraquinone & & & + & + & +++ & + \\
\hline Cardiac glycosides & - & - & - & - & - & \\
\hline Cyanogenic glycosides & - & - & - & - & - & - \\
\hline Flavonoides & + & + & + & + & + & + \\
\hline $\begin{array}{l}\text { Reducing and non-reducing } \\
\text { carbohydrates }\end{array}$ & - & - & +++ & +++ & +++ & - \\
\hline
\end{tabular}

Parenthesis $=$ Plant part

$+++=$ Appreciable amount

$++=$ Moderate amount

$+=$ Trace amount

- = Completely absence

tained cardiac glycosides and cyanogenic glycosides. Reducing and non-reducing carbohydrates were found in $P$ discoideus, O. gratissimum and T. avicennioides (Table 4).

\section{Discussion}

Medicinal plants constitute an effective source of both traditional and modern medicines, herbal medicine has been shown to have genuine utility and about $80 \%$ of rural population depends on it as primary health care. Over the years, the World Health Organization advocated that countries should interact with traditional medicine with a view to identifying and exploiting aspects that provide safe and effective remedies for ailments of both microbial and non-microbial origins[29].

The results of the study indicated that four out of six medicinal plants commonly used by traditional medical practitioners to cure skin and upper respiratory tract infections such as pneumonia, carbuncle, purple, impetigo and tonsillitis were active against hospital strains of MRSA. The crude extracts of $B$. ferruginea and A. conyzoides were weakly active against MRSA strains with ethanol extract of both plants exerting stronger antibacterial activity than water extracts. Previous studies by Ogbeche et al.[17] and Oluyemi[18] indicated that the crude extracts of these plants were effective against $S$. aureus. The present study was slightly conformed to their findings but the only area of concern is that while their studies only dealt with the effect of crude extracts on $S$. aureus, our study focused on the effect of crude extract on the MRSA, and determination of both MIC \& MBC values of the extracts.
For example, the MIC values of 30.6 and $43.0 \mathrm{mcg} / \mathrm{ml}$ obtained for ethanol extracts of $B$. ferruginea and $A$. conyzoides in this study were lowered than their corresponding water extracts of 55.4 and $71.0 \mathrm{mcg} / \mathrm{ml}$. Similarly, MBC values of 63.6 and $84.2 \mathrm{mcg} / \mathrm{ml}$ were recorded for ethanol extract of $B$. ferruginea and $A$. conyzoides respectively (Table 3 ). These values were too high to be considered active against the pathogen. It is worthy of note that traditional medical practitioners used these plant extracts solely without combining with other plant extracts for the treatment of MRSA-associated skin and respiratory diseases. This finding may disagree with the traditional therapeutic indications claimed on these plants we therefore suggest the immediate stoppage of their traditional use against MRSA-associated diseases in Lagos, Nigeria. However, the in-vitro inactivity of these plants on MRSA may not necessarily translate to their in-vivo inactivity but the extracts may probably be playing immuno-modulatory roles in the body system. Bever[30] had documented immunodulation of chemical compounds from medicinal plants many of which have been proved to be inactive or weakly active in-vitro against pathogens. In this study, we are unable to determine immuno-modulating action of these plants due to lack of facilities.

Our investigation further showed that both water and ethanol extracts of $T$. avicennioides, $P$. discoideus, $O$. gratissimum and A. wilkessiana were active against $S$. aureus and MRSA. The MIC value of the four active plant extracts obtained in this study were lower than the MBC values suggesting that the plant extracts were bacteriostatic at lower concentration and bactericidal at higher concentration. The ethanol extract of the four plants exerted greater 
antibacterial activity than corresponding water extract (Tables 2 and 3 ) at the same concentrations. These observations may be attributed to two reasons; firstly, the nature of biological active components (saponins, tannins, alkaloids and anthraquinone) which could be enhanced in the presence of ethanol. It has been documented that tannins, saponins and alkaloids are plants metabolites well known for antimicrobial activity[31]. Secondly, the stronger extraction capacity of ethanol could have produced greater number of active constituents responsible for antibacterial activity.

Traditionally, leaves of $O$. gratissimum and A. wilkesiana and barks of $T$. avicenniodes and $P$. discoideus are soaked in ethanol or water (in case of patients forbidding alcoholic intake due to religious belief) for days, large quantities of these extracts, which lack specific concentration are usually administered to patients. Our results therefore tend to support the traditional claim that these four medicinal plants are preferably extracted in ethanol. Strong vibriocidal activity of water and ethanol extracts of T. avicennioides and typhoidal activity of aqueous extracts of $O$. gratissimum had been reported in Lagos, Nigeria $[15,16]$.

The result of phytochemical screening of six plants indicated the presence of tannins, alkaloids and saponins. Interestingly, only the four plant extracts that were active against MRSA in this study contained at least trace amount of anthraquinone (Table 4). It is therefore most probable that the presence of anthraquinone contributed to antiMRSA activity observed. We were unable to carry out bioautography of the extracts due to lack of facilities.

\section{Conclusion}

Our results therefore offer a scientific basis for the traditional use of both water and ethanol extracts of A. wilkesiana, O. gratissimum, T. avicennioides and P. discoideus separately against MRSA-associated skin and respiratory diseases. But in vivo studies on these medicinal plants are necessary and should seek to determine toxicity of the active constituents, their side effects, serum-attainable levels, pharmacokinetic properties and diffusion in different body sites. The antimicrobial activities could be enhanced if the active components are purified and adequate dosage determined for proper administration. This may go a long way in curbing administration of inappropriate concentration; a common practice among many traditional medical practitioners in Nigeria. This study represents the first preliminary report on anti-methicillin resistant Staphylococcus aureus activity of the crude extracts of these medicinal plants in Lagos, Nigeria.

\section{Competing interests}

The author(s) declare that they have no competing interests.

\section{Authors' contributions}

KOA: Conceived the study, designed, coordinated, screened the MRSA strains used and drafted the manuscript.

OO: Carried out the extraction, susceptibility testing and determined MIC \& MBC values of the extract.

CEO: Participated in both extraction and susceptibility testing.

CCI: Carried out susceptibility testing and determined MIC and MBC of the extracts.

KAF: Participated in phytochemical screening and susceptibility testing.

\section{Acknowledgements}

We hereby acknowledge the financial support for this study by The Ford Foundation through the Centre for Development and Democratic Studies of Lagos State University (LASU/CDDS). We are also grateful to the Management of the various hospitals used as study centers and the Nigerian Institute of Medical Research, Yaba, Lagos for support and technical assistance. We are equally gratefull to $\mathrm{Mr} \mathrm{E} O \mathrm{O}$ Omonigbehin for his technical assistance and Mrs O. M. Lamidi for the secretariat work.

\section{References}

I. Waldyogel FA: Staphylococcus aureus (including Toxic Shock Syndrome). In Douglas and Benett's Principles and Practice of Infectious Disease Edited by: Mandell GL, Benett JE, Dolin R, Mandell DS. Churchill Livingstone, New York; 1995: 1754- 1777.

2. Chambers HF: Methicillin Resistance in Staphylococci: Molecular and Biochemical basis and Clinical implications. Clinical Microbiology Reviews 1997, 10(4):781-79I.

3. Thomsberry C, McDougal LK: Successful use of broth microdilution in susceptibility of tests for methicillin resistance (heteroresistant) Staphylococci. Journal of Clinical Microbiology 1983, 18:1084-1091.

4. Kloos WE, Bannerman TL: Staphylococcus and Micrococcus. In Manual of Clinical Microbiology Edited by: Murray PR, Barron EJ, Pfaller, MA, Tenover FC, Rolken RH. ASM Press, Washington, D. C; 1995:282-298.

5. Zhao W, Zhi-quin H, Okubo S, Hara Y, Shinmamura T: Mechanism of synergy between Epigallo catechin Gallate and B-Lactams against MRSA. Antimicrobial Agents and Chemotherapy 200I, 45: $1737-1742$.

6. Voss A, Milatoric D, Schwarz CW, Rosdahl VT, Brarenny L: Methicillin Resistant Staphylococcus aureus in Europe. European Journal of Clinicl Microbiology and Infectious Disease 1994, I3:50-55.

7. Neeling AJ, Leeuwen WJ, Schouls MS, Veen-Rutgems A, Beuders AJ, Buiting M, Hol C, Sabbe JM: Resistance of Staphylococci in the Netherlands: Surveillance by an electronic network during 1989-1 1995. Journal of Antimicrobial Chemistry 1995, 41:93-101.

8. Sanders CC, Sanders $C \mathrm{Jr}$, Thomson KS: Fluoroquinolones resistance in Staphylococci: New Challenges. European Journal of Clinical Microbiology and Infectious Diseases 1995, I4:S6-SII.

9. Smith TL, Pearson ML, Wilcox C, Cruz MV, Lancaster B, Robinson B, Tenoner FC, Zervos MJB, White DJ: Emergence of Vancomycin Resistance in Staphylococcus aureus. New England Journal of Medicine 1999, 340:493-501.

10. Liu CX: Development of Chinese medicine based on pharmacology and therapeutics. J Ethanopharmacol 1987, 19:1 19-123.

II. Desta B: Ethiopia traditional herbal drugs part II: antimicrobial activity of 63 medicinal plants. J Ethnopharmacol 1993, 42:129-139. 
12. Anesini C, Perez C: Screening of plants used in Argentine folk medicine for antimicrobial activity. J Ethnopharmacol 1993, 39:119-128.

13. Nick A, Rali T, Sticher O: Biological screening of traditional medicinal plants from Papua New Guinea. J Ethnopharmacol 1995, 49: 147-156.

14. Gill LS, Akinwunmi C: Nigerian Medicine Practice and Beliefs of the Ondo People. J Ethnopharmacol 1986, 18:257-266.

15. Akinside KA, Olukoya DK: Vibrocidal activities of some local herbs. J Diarhoeal Dis Res 1995, I 3: I 27-I 29.

16. Akinyemi KO, Bayagbon C, Oyefolu AOB, Akinside KA, Omonigbeyin EA, Coker AO: Antibacterial screening of five indigenous Nigerian medicinal plants against $S$. typhi and $S$. paratyphi. Journal of Nigerian infection control association 2000, 3(1):30-33.

17. Ogbeche AK, Ajayi GO, Onyeneta P: Antibacterial activities of the leaf extract of Ageratum conyzoides. Nig Qt J Hosp Med 1997, 7:397-399.

18. Oluyemi A: Bridella ferrugenea. Medicinal Plants and their therapeutic uses in the South West Zone of Nigeria. Technical report. Nigeria 1998:101.

19. Olowokudejo JO, Pereira-Sheteolu O: The taxonomic value of epidermal characters in the genus Ocimum (Lamiaceae). Phytomorphology 1988, 38:147-158.

20. Akinde BE, Odeyemi OO: Extraction and Microbiological Evaluation of the Oils from the leaves of Acalypha wilkesiana. Nig Med J 1987, 17:163-165.

21. Cowan ST, Steel S: Manual for the Identification of Medica Bacteria. Edited by: Barrow GI, Feltham RKA. Cambridge University Press; 1993:32.

22. National Committee for Clinical Laboratory Standards: Dilution anti-microbial susceptibility tests for bacteria that grow aerobically. Approved Standard: NCCLS document 1993:M7-A3.

23. Sardari SA, Gholamreza R, Mcrtich G, Daneshtalab M: Phytopharmaceuticals. Part I: Antifungal Activity of Selected Iranian and Canadian Plants. Pharm Biol 1998, 36:180-188.

24. Wall ME, Eddy CR, McClenna ML, Klump ME: Detection and estimation of steroid and sapogenins in plant tissue. Analytical Chemistry 1952, 24:1337-1342.

25. Sofowora A: Medicinal Plants and Traditional Medicines in Africa. Chichester John, Willey \& Sons New York; 1993:256.

26. Trease GE, Evans WC: $\boldsymbol{A}$ Text-book of Parmacognosy. Bailliere Tinall Ltd, London; 1989:53.

27. Harborne JB: Photochemical Methods: A Guide to Modern Techniques of Plant Analysis. Chapman A \& Hall. London; 1973:279.

28. Kapoor LD, Singh A, Kapoort SL, Strivastava SN: Survey of Indian Medicinal Plants for Saponins. Alkaloids and Flavonoids. Lloydia 1969, 32:297-302.

29. World Health Organization (WHO): The promotion and development of traditional medicine. Technical report series 1978:622.

30. Bever BO: Anti-infective activity of Chemical Components of higher plants. In Medicinal Plants of Tropical West Africa Cambridge University Press; 1986:68.

31. Tschesche R: Advances in the chemistry of antibiotics substances from higher plants: Pharmacognosy and phytochemistry. In Proceeding of the Ist International Congress, Murich, 1970 Edited by: Wagner H, Horharmmer L. Springer-Verlag, Berlin Heidelberg, New York; 1971:274-289.

\section{Pre-publication history}

The pre-publication history for this paper can be accessed here:

http://www.biomedcentral.com/1472-6882/5/6/prepub

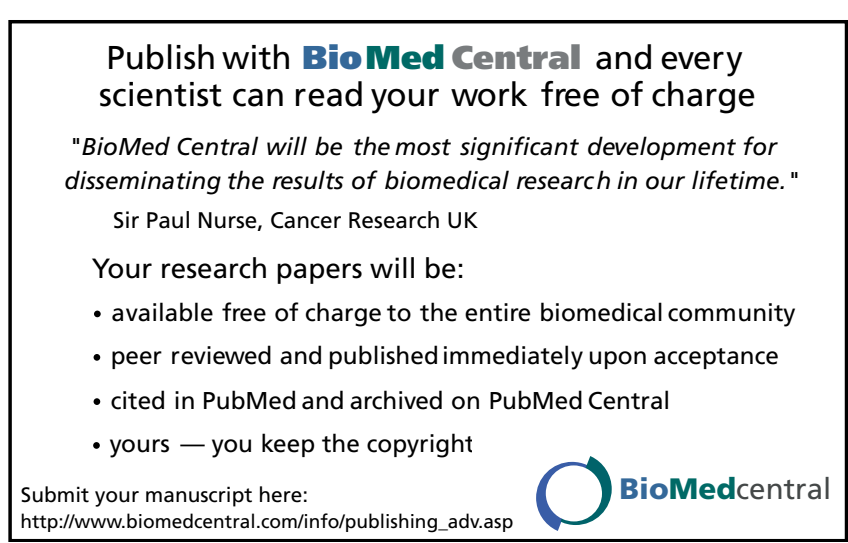

